\title{
Corporate Social Responsibility (CSR) Practices and the Challenge of Taking Ownership: A Case Study of Frustrations of Shell Petroleum Development Company in Niger-Delta Region of Nigeria.
}

\author{
Dr. Adeyeye Adewole \\ Ondo State University of Science and Technology
}

\begin{abstract}
The paper examines the challenge of taking ownership by stakeholders as standard operational baseline for effective and sustainable CSR practices. It highlights the preponderance of incorporating stakeholders into mainstream activities in a professional that entails pro-active stakeholders' participation and involvement by multinational corporations in order to maximize inherent benefits of CSR programs. Using the experience of Shell Petroleum Development Company (SPDC) in the NigerDelta region of Nigeria as a case-study, the paper analyses the danger and the attendant frustrations that are sure to erupt when companies deliberately or inadvertently refused to handle CSR initiatives without eliciting required supports of critical stakeholder like host community based on standard taking ownership model towards sustainable CSR practices.
\end{abstract}

Keywords: Corporate Social Responsibility, Taking Ownership, Shell Petroleum, Development company Niger Delta Region

\section{INTRODUCTION}

Despite initial debates and criticisms that trailed corporate social responsibility (CSR) in the years past, it is no longer in doubt that corporate social responsibility (CSR) practices have become almost indispensable in emerging business configurations. (Buchholz, 1991), (Kaufmann M \& Olaru.M, 2012), (Adeyanju, O.D, 2012). Hence, there are unanimity and increase awareness that CSR is a success factor in modern business activities. Corporate Social Responsibility (CSR) has become indispensable competitive tool for modern business activities. The implication is that long-term sustainable existence of different shades of businesses be it (local, international; small, medium and large scale enterprises) depends to a greater extent on how each business is able to respond to direct or indirect interests of proximate stakeholders. Recent practical experiences by professional business managers and reports by researchers have indicated that there is a way in which negative reactions by corporate stakeholders can frustrate business existence. Imagine what happens, if consumers of a particular line of products choose to boycott certain products when they strongly believed that their critical interests have not been adequately addressed by business entity. Let us also imagine possible effects of community antagonisms and attacks if a given community genuinely feels that her interests have being jeopardized by operating effects of business activities. The bottom line is that stakeholders' involvement and concerns have become serious issue to contend with in modern business management. Managing Stakeholders involvement and concerns entails how companies are able to accommodate stakeholders' interests and turn those interests into success factors based on modern corporate social responsibility (CSR) model. 
The philosophy of corporate social responsibility (CSR) is predicated on emerging management model which underscore need for companies to consider impacts of business activities on critical stakeholders, such as consumers, host communities, government, employees, shareholders as well as the environment. The benefits of corporate social responsibility (CSR) practices to corporate organizations cannot be underestimated. (Chinedu \& Chinua 2001) have confirmed that corporate social responsibility (CSR) practices help organizations to manage risks, particularly those that are associated with stakeholders' criticism, consumerists' activism and community insurgencies. It also helps with brand differentiations, and can assist companies to promote their unique selling points. Other advantages of corporate social responsibility (CSR) include enhanced image, guarantee of long term business relationships even in the face of threat to survival.

However, due to existing voluntary nature of corporate social responsibility (CSR) initiatives, most organizations do not accord it, the seriousness it deserves. Others use approach that suits them, This has made it somewhat difficult to develop a fool proof correlational impact analysis of such approaches particularly those that does not conform with popular CSR operational practices. Some use wrong approach outrightly while in some cases, the approaches adopted by some organizations are haphazard. Apart from engaging in corporate philanthropy, another major dimension to CSR practices which has become conspicuous in recent times is corporate CSR interventionists' initiatives. With CSR interventionists initiatives, corporate organizations analyze and deploy indicators such as community development projects, educational facilities, HIV/AIDS campaign programs, youth empowerments, donations to federal, state and local governments as veritable CSR Agenda to engender desired relationship with stakeholders. As reasonable as these dimensions may seems, they all stand the chance of not being able to achieve desired result if the program contents of corporate social responsibility (CSR) and activities are not in proper tune with stakeholders' ownership and participatory mode.

It can become a waste of time and resources when corporate social responsibility (CSR) agenda is not well articulated, and professionally managed. It can also result in outright misplacement of efforts if it fails to engender stakeholders' intense or capture genuine interest in the context of participatory corporate social responsibility agenda. Corporate social responsibility (CSR) practices may back-fire if business organizations are not strategic in their corporate social responsibility (CSR) prosecution. The effects of non-involvement of stakeholders could easily result into despicable misunderstanding and unfriendliness which may negatively impinge on business activities. Above all, it would be frustrating and most disastrous if a company thinks she has done enough; and stakeholders still have good reasons to believe that such company has not lived up to expected legitimate expectations. What this simply means is that CSR practices can be entirely misdirected if a company and its stakeholders do not operate on the same wavelength. Lack of stakeholders' involvement can lead to animosity. Both parties would seems to be talking and one does not seem to comprehend the other. It may be quite disappointing if a company had initiated various corporate social responsibility (CSR) activities and stakeholders were not in the picture or were not carried along in order, at least to appreciate what the company is doing. The company can only be appreciated when critical corporate stakeholders are involved in the original corporate CSR agenda.

Unfortunately, this is the root of frustrations that are being experienced by most companies in corporate social responsibility (CSR) practices. Frustrations orchestrated by stakeholders are too costly and inimical to sustainable growth and development of businesses. Stakeholders' support is crucial to overall success of company. When stakeholders' withdraw their support over a long period of time, it could ultimately lead to prolonged frustrations on the part of concerned business and some of the likely consequences are business failure, pull-out and 
possible collapse of business activities. All these are predictable outcomes of business organizations that refused to enlist stakeholders' ownership approach in their corporate social responsibility (CSR) practices.

Stakeholders' ownership approach enjoins involvement of stakeholders' from the beginning of corporate social responsibility (CSR) planning. Stakeholders are also expected to be involved in other subsequent processes which include program designs, project implementation and periodic monitoring. When companies shun stakeholders' and do not involve critical stakeholders in their corporate social responsibility (CSR) practices, they stands the risk of outright misrepresentation, antagonism, regrettable frustrations, recapitulation and possible disruptive business activities which may eventually lead to pull-out as with the case of Shell Petroleum Development Company (SPDC) in the Niger-Delta Region of Nigeria.

Shell Petroleum Development Company (SPDC) which is our case study is an example of how not to practice CSR without involving stakeholders particularly critical host communities. It also exemplifies frustrations that are bound to occur when companies fail to adequately and strategically incorporate stakeholders into their CSR programs. It is also a good example of how key business stakeholders, particularly critical host communities, can dangerously turn around to become a damning threat to company's activities if companies refuse to get them incorporated one way or the other. Various research works have been carried out on the implications of corporate social responsibility (CSR) practices and the role it play in business growth and development. However, there are scanty literatures on the effects of stakeholders' engendered antagonisms against corporate organisations leading to frustrations on the part of concerned corporate entity. The study critically examines the unique experience of Shell Petroleum Development Company (SPDC) in the Niger Delta Region of Nigeria. This is against the backdrops of claims by Shell Petroleum Development Company (SPDC) that she had embarked on various corporate social responsibility (CSR) program which in their calculations ought to have been reciprocated by host communities. The Shell experience is particularly instructive for companies that believed in stakeholders' proactive engagement which involves legitimately integrating stakeholders towards sustainable corporate social responsibility (CSR) practices.

\section{PETROLEUM EXPLORATION AND SHELL PETROLEUM DEVELOPMENT COMPANY (SPDC) IN NIGERIA}

Shell Petroleum Development Company (SPDC) is a member of the Shell Group worldwide. The company is the operator of Nigerian Joint Venture Oil business through the Nigerian National Petroleum Corporation (NNPC). The company became involved after discovery of the first commercial oil field in Oloibiri in the late 50's and since then, its activities in petroleum business have expanded greatly. Shell Petroleum Development Company (SPDC) participates actively in massive exploration, production and distribution of different range of petroleum products. It operates in an oil mining lease area of about 31,000 square kilometers in the Niger Delta region of Nigeria. From its base in the Niger Delta, the company runs a network of approximately 6000 oil pipelines and flow lines, 87 flow stations, about 1000 producing wells in addition to 8 gas plants. To underscore the exhaustive nature of Shell in this area, the oil business of Shell is responsible for more than $80 \%$ of Nigeria's total revenue while about $14 \%$ of Shell's total global productions come from their activities in the Niger-Delta region of Nigeria according to global oil report. 


\section{SHELL, ITS HOST COMMUNITIES AND THE CSR CHALLENGE IN THE NIGER-DELTA REGION}

The Niger Delta region is an epitome of oil wealth. It holds at least 20 billion barrel of oil reserves, while the Shell led-petroleum activities pumps about 2 million barrels of oil daily from the region. Most activities of Shell Petroleum Development Company (SPDC) are concentrated in the Niger Delta region. The region represents critical area where exhaustive production and exploratory activities take place thereby underscores its strategic importance. Activities of Shell Petroleum Development Company (SPDC) in the Niger Delta region according to (Chinua \& Chinedu, 2001); (Mbidoka, 2004) include extractions , drilling, earthmoving activities, deep-sea explorations, opening of roads, bush clearing, deployment of heavy equipments, digging of borrow pits, massive construction works which include petroleum terminals. Shell constructed large terminals, including the Forcados and Bonny terminals. Some of the terminals are capable of storing 13 million barrels of crude oil. There are pipeline network that criss-cross parts of the region for easy crude oil transportation. Shell is also involved in deep water drilling across the adjoining sea and water in the Niger Delta region. There is significant gas exploration with substantial gas flares. The Niger Delta region is inhabited by Nigerian minority groups such as Itsekiris, Urhobos, Ijaws, Ilajes, Ogonis Kalabaris' Efiks, Ikwere's. Given this scenario, available reports by (Kingsley \& Tony, 1998) (Bosen, 2002); (CNN, 2004); (Emakpe, 2005)and others indicates various ways in which Shell operational activities impacts negatively on its host Niger-Delta communities. These are highlighted as follows:

\section{Human Displacements:}

As Shell Petroleum Development Company (SPDC) expands its exploration activities to capture new oil opportunities, it embarks on human displacements with unpalatable interferences and painful disruptions to human settlement equilibrium. Farmlands, houses and other settlements were made to be supplanted by erected oil facilities. This is one of the major causes of sporadic clashes between Niger Delta oil producing host communities and Shell led oil companies. Expectedly, the exploratory agenda of oil companies do not tally or conform to the desires of host communities. The host communities prefer their cherished traditional symbiotic relationship with natural environment. Traditional approach to life by indigent people of Niger Delta is being dislodged by petroleum exploration activities of Shell Petroleum Development Company (SPDC).

\section{Oil Spills:}

While, oil spillage may not be unexpected in an environment where there is enormous petroleum exploration, Shell Petroleum Development Company (SPDC) leaves in its track massive oil spills across land and sea in the Niger-Delta region. Oil-related chemicals spill on available surfaces across the earth and water in Shell operating areas. When this happens, the spillage kills plants and harm animals. In addition, water is polluted and the earth is defertilized for good planting. The factsheet on Ogoni struggle reports that when this happens, it makes water unfit for use, fish and other animals are killed while aquatic life is adversely affected leading to major disruptions of ecosystem.

\section{Gas flaring:}

Another critical effect of Shell Petroleum Development Company (SPDC) activities on its Niger Delta host communities is gas flaring. With improved technological advances, it is expected that gas, a major output of oil exploration should be carefully packaged for additional benefits. In spite of this, the Niger Delta region for a longer period has continued to suffer round the clock gas flare. Although, Shell Petroleum Development Company (SPDC) claimed to have made some progress in mitigating effect of gas flaring, but between 1998 and 1999 alone, oil 
companies flared about 1.7 billion standard cubic meters of gas. The negative effects of gas flaring are unimaginable. Emakpe, (2008) affirms that recurring gas flares close to Niger Delta host communities' precipitates air pollution. It contributes to global warming. It also leads to many destructive air hazards

\section{Health Risks:}

Shell exploratory activities also pose serious health implications to its host communities in the Niger Delta region. Apart from the fact that host communities are made to contend with polluted water and other related health risks; there is strong challenge of hydro-carbon contamination that over-hangs every inhabitants in Niger Delta region. There is also the danger of outbreak of different kinds of diseases. Innocent and gullible community members face the threat of the spread of HIV/AIDS by rich oil workers. The implication of this is that there is critical challenge of comprehensive health system to address negative health effects of oil explorative activities on host communities in Niger Delta region.

\section{Impoverishment:}

Shell Petroleum Development Company (SPDC) activities promote and exacerbate poverty in the Niger Delta region. Encroachments on farmlands and water ways as a result of oil spillage and massive water pollution have denied Niger Delta host communities sources of livelihood. Oil spills make farm lands unfit for cultivation, available plants are easily exterminated while fishes are poisoned to death. In these situations, income level is reduced, unemployment is encouraged and poverty is aggravated amongst people that depend on farmland and water for sustenance. By implications, Shell Petroleum Development Company (SPDC) exploratory activities have engendered and perpetuate personal and community poverty across NigerDelta Region of Nigeria.

\section{CSR AGENDA AS A MEANS OF CUSHIONING EFFECTS OF ACTIVITIES ON HOST COMMUNITIES}

Against the backdrop of arrays of problems with host communities in the Niger Delta region, there is fundamental challenge of instituting responsive corporate social responsibility (CSR) practices if the business of Shell is to be sustained in Niger Delta region. Notwithstanding the non-availability of compelling legislations capable of forcing Shell to embark on various remediation programs in order to mitigate negative effects of exploratory activities on host communities, the weak regulatory framework should rather be an impetus for Shell Petroleum Development Company (SPDC) to put in place responsive and dynamics corporate social responsibility (CSR) practices.

Shell should have used her CSR opportunity to effectively palliate host communities of their injuries if Shell business activities in the Niger-Delta region are to be sustainable on the long run. It must be stated unequivocally that the way and manner companies handle critical corporate social responsibility (CSR) challenge like the situation in Niger-Delta often go a long way to determine whether they'll lose out and become frustrated in business/community blame game. In this particular circumstance, what is required is practical CSR agenda. Practical CSR agenda to that can effectively help to mitigate negative effects of business activities. If company is able to proactively handle situation, success is pretty assured. But if not, it becomes a major calamity and instance of corporate irresponsibility with attendant consequences such as business failures and possible pullout.

In the case of Shell Petroleum Development Company (SPDC), the company claimed they respond to some of the challenges posed by host communities in Niger-Delta region, but the 
results achieved leave much to be desired in view of Shell's frustrating experiences and eventual pull-out.

\section{SHELL CSR ACTIVITIES IN NIGER-DELTA REGION}

Available evidences point to the fact that Shell Petroleum Development Company (SPDC) is guided by two principles in its corporate social responsibility (CRS) activities. The first principle is Shell General Business Principles (SGBP). The kernel of Shell General Business Principles (SGBP) is commitment to following established principles in all activities worldwide including the Niger Delta region. These are principles specially designed by shell to guide business operations across the globe includes:

- Emphasis on compliance

- Growing concern about security Post - 9/11

- Emphasis on social performance and with communities.

- Shell enterprise first values and behaviors

- Development of sustainable principles

- Clarity on treatment of facilitation payments

The other aspect of Shell Petroleum Development Company (SPDC) corporate social responsibility agenda is code-named issue management initiatives. The issue management initiative focuses on dealing with specific corporate social responsibility (CSR) situations as they unveil. According to Shell, an issue is any subject of interest or concern by stakeholders in matters related to company's activities. When issues are raised, what Shell does is to listen to those issues and try to respond. Based on this approach in particular, Shell Petroleum Development Company (SPDC) has been able to categorize issues that are paramount to its host community in the Niger Delta region. These issues, according to Shell, include security, gas flaring, remediation plans against destructive outcomes of exploratory activities in the NigerDelta, Ogoni and Human Rights. Having identified these issues, Shell attempts to provide explanations for them. In addition, Shell respond to most of the problems based on the template of their issues management approach to CSR practices. On the basis of this, shell affirms that the value of their community assistance program runs into \$32 million as at 1997. The company also claimed to have employed about $57 \%$ of their total workforce from the Niger Delta local communities. Shell claimed they have preference to indigenous contractors as a way of empowering host communities. As part of this issue based approach, they also claimed to have instituted Shell Development initiative in which host communities are made to have a say in many development projects. Shell Petroleum Development Company (SPDC) also claimed to have engage host community by working with local organisation to ensure benefits of its resources are adequate impacted to communities and businesses.

However a critical appraisal of Shell Petroleum Development Company (SPDC) corporate social responsibility (CSR) activities clearly indicates that the CSR approach lacked the depth and profundity to tackle the critical challenge that confronts Niger-Delta host communities as a result of Shell exploratory activities. Shell corporate social responsibility (CSR) activities lacked the finesse to pro-actively appreciate the critical nature of problems they perpetrated on host communities. It also did not seem to gather enough muscle to address the challenge created for the host communities head on. Instead, Shell seems to focus only on trivialities emanating from her established corporate principles which they could not properly align with development exigencies in the Niger Delta region and the problems its pose for her sustainability. Little wonder why the high sounding Shell General Business Principles (SPDC) did not bring about substantial physical and environmental remediation to host communities in the Niger-Delta. Also, the issue management strategy is rather unstructured in conception. It is sporadic both in designs and applications. Hence, most of the various projects embarked 
upon by Shell failed to placate host communities because the project did not emanate through genuine stakeholders engagement. If the results of devastating effects of oil activities is anything to go by, according to Watts (2005), there is no way Shell could have successfully captured the needs of stakeholders in her approach as it were until and unless the host communities in Niger Delta region are practically involved both in CSR project conception and applications.

This is the critical missing points. It is also a big lesson for all multinational companies all over the world. The apparent dissatisfaction by host communities eventually led to high level restlessness. With increased restlessness by host communities, Shell Petroleum Development Company out of frustration introduced unorthodox dimensions. This includes the use of various reactionary methods that completely foreclose healthy corporate/community relationships in strict CSR sense. Some of these methods include:

- Complicity with the federal government of Nigeria in order to deal with what they termed as business "Saboteurs".

- Using sabotage as a justification for non-payment of compensations to genuine community members whose property and assets were affected by exploratory activities.

- Heavy reliance on heavy capital investments in security (personnel and materials to deal with seemingly offensive host communities) instead of placating them through stakeholders' involvements.

- Use of divide and rule tactics to factionalise and create enimity among host communities

- Repression of legitimate protests by Niger-Delta host communities.

- Pull-out Threats.

The adoption and prosecution of the above approaches by Shell Petroleum Development Company (SPDC) in her dealings with host communities marked the beginning of strained relationship. The situation later becomes worse with each passing days. The effects of this approach on host communities in the Niger-Delta and the entire business environment according to Chinedu, (2001), Emakpe, (2008) leave much to be desired. Cable Network News (CNN) (2010) asserts that evidences abound that the host communities were increasingly agitated. And the gap between Shell Petroleum Development Company (SPDC) and her host communities were becoming wider and wider. Shell seems unrepentant in activities that are injurious to host communities even as she relies on security force with back up of federal authority to force her wish on her host communities.

These approaches are quite antithetical to proper CSR management models Jones, (1980), Freeman, (1994), Jenson, (2001), Hendson, (2004). Little wonder that the end results heightened dysfunctional relationship. Other effects include sustained environmental degradation leading to serious clashes as a consequence of agitations over stakeholders' abandonment in the Niger-Delta region. Unperturbed, massive deforestation continues unabated. There are persistent earth dislocation; perennial land and water pollution. Oil spillage without concrete effort to mitigate the effects on host communities. Shell bluntly refused to learn from lessons developed by Gulbaridsen \& Moe, (2005), Watts (2005) as there were no conscious efforts to redress collateral harms that are being unleashed on both the host communities and environment as a result of Shell exploratory activities. Apart from the fact that there were also no well-orchestrated compensation packages for stakeholders and communities negatively affected by oil activities in the thinking of Papineau \& Kiely, (1996); Shell Petroleum Development Company (SPDC) did not put in place appropriate long and medium term strategic action-plans that takes stakeholder particularly host communities into adequate consideration. Another significant feature of the outcomes of shell CSR activities 
in the Niger Delta region is that the region is gradually being impoverished due to aggravated damage occasioned by Shell exploratory activities without corresponding efforts at systematic and adequate restoration. The Niger-Delta region pathetically, remains one of the least developed region in Nigeria despite the fact that the region generate enormous resources through Shell led petroleum exploration. An independent social audit by the West African Society on Business Ethics (WASBE, 2007), indicates that the Niger Delta region lacks good road, regular supply of electricity, good schools and there is also no portable water. The audit report also indicates that the region lives on peasant farming and fishing both on lands and water that were been gradually destroyed. Above all, the Niger Delta region is under the yoke of excruciating poverty with unemployment soaring high. Given the above indications, the Shell approach to corporate social responsibility (CSR) in Niger-Delta region is nothing but a complete failure. It is analogue to what Akanni, (2008) refer to as corporate social irresponsibility.

All these resulted into alarming spates of agitations against Shell Petroleum Development Company (SPDC) by its host communities in the Niger- Delta region. At a particular period, the agitations metamorphosed into full-fledged violence and protests which were marked by destructions of Shells' equipment and oil installations. Other features of the resultant protests against Shell include heightened occupation of oil installations, kidnapping of oil workers and physical attacks. The irony is that instead of adopting sustainable ways out of the imbroglio by Shell, the host communities were harassed. The expectation was that the host communities would be subdued through force. This approach degenerated into mutual suspicion. Palpable contradictions soon enveloped existence of host communities and those of the oil officials within the same region thereby giving the impression of business army of occupation instead of cooperation and partnership for mutual benefits. In nearly all the oil staff quarters, there is opulence. Shell staff quarters are well-fenced. There is regular and uninterrupted supply of electricity. Residents in the quarters have access to clean water and elitist medical facilities. In the same vicinity where there is such opulence, the host communities wallow in abject poverty. They live in mosquito infested swamps and farmland. As the situation became worse and more critical, the Niger Delta region increasingly becomes unfavorable for peaceful business activities. There were deadly attacks on Shell activities, destructions of installations leading to full scale violence, killing and kidnapping of oil workers. All these underscore the nonworkability of the Shell approaches in handling of its host communities.

\section{SHELL CSR FRUSTRATIONS AND PULL-OUT THREAT DUE TO LACK OF STAKEHOLDERS PRO-ACTIVE ENGAGEMENT.}

Ultimately, Shell Petroleum Development Company (SPDC) became frustrated. She suffered incessant business disruptions. The company was overwhelmed by repeated destructions of oil installations. Workers were made to face incessant kidnap and harassment. There were massive violence. At a point, Shell Petroleum Development Company (SPDC) became hugely frustrated and she eventually embarked on pull-out threat through major business divestments. Essentially, Shell attributes her bitter and frustrating experience to what she termed peculiar socio-political environment in Nigeria which remained unfriendly because of problems of general insecurity and deepening poverty. Shell also claims that gangsters', kidnapping and violence have become lucrative business among host communities such that Shell is already programmed to fail regardless of the type of initiative she deployed.

The position of this paper is that Shell Petroleum Development Company (SPDC) has left undone what she is expected to do in corporate social responsibility sense. Genuine corporate social responsibility (CSR) practices guarantee desired equanimity and attainment of desired objectives if effectively prosecuted (Davis. K 1978) (Jones, 1980); (Bowie, 1991). Corporate 
social responsibility (CSR) enjoins understanding and support in business dealings with cross sections of stakeholders which include host communities, consumers, shareholders, workers etc. (Marsdan et'al 1998), (Adeyeye,A 2005). Effective stakeholders' engagement is indispensable for any meaningful \& sustainable CSR practices (Windor, 2001). Sincere and result oriented corporate social responsibility (CSR) would not regard host communities as mere object of exploitation in business relationships. The truth is that Shell Petroleum Development Company (SPDC) has underestimated the power of stakeholders' involvement in all her corporate social responsibility (CSR) activities. The Company failed to involve stakeholders' in activities from the onset and this entails allowing stakeholders to take ownership of the process in corporate social responsibility (CSR) sense. The matter became worse because Shell host communities in the Niger-Delta have been abandoned for too long. There were no spirited efforts to strategically incorporate host communities into mainstream activities in a manner that elicit confidence as advocated by, (Michael J. 2001) and other researchers in order to maximize stakeholders strength towards corporate sustainable activities.

The self-orchestrated frustrations experienced by Shell Petroleum Development Company (SPDC) which has culminated incessantly into business stoppage and pull-out threats is specifically due to the fact that there were no strategic community stakeholders' involvement by Shell business activities in Niger Delta region. Given the peculiarity of Shell activities in the Niger Delta region, there should be preponderance of deliberate community integration blueprints in terms of infrastructural assistance, environmental revamping, integrated health intervention mechanisms and other education and human capacity development calculations. Unfortunately, the host communities were over-time isolated and maligned. This is also without regard to the fact that host communities are at the receiving end of negative effects of shell business activities. There were no programs which host communities can identify with in terms of critical inputs. There were also no deliberate efforts to allow host communities take ownerships in order to effectively assist in driving corporate social responsibility practices. By allowing this to happen, Shell has elicited prima facie conditions for mutual suspicions and distrusts from her host communities. This is most undesirable for sustainable business relationship particularly where long term business sustainability depends to a large extent on the supports of host communities. Hence, Shell had to pay the dangerous price of being frustrated and eventual systematic business pull-out.

The truth is that Shell Petroleum Development Company (SPDC) should have known that she owes its existence and long term sustenance in the Niger-Delta Region to its host communities and the communities are clearly aware of this. In strict compliance with CSR stakeholders' involvement template, there is no reason why Shell Petroleum Development Company (SPDC) should not have adopted the Niger-Delta Region for special camaraderie. This can be achieved by developing cordial relationship through stakeholders' involvement in Shell activities. Shell Petroleum Development Company (SPDC) ought to have put in place appropriate strategy on corporate social responsibility (CSR) model that gives high premium on host communities as major stakeholder in order for them to take ownership of CSR process management. This would have demonstrated Shell's sensitivity and engender prompt response of all shades of interest in a manner that distinguishes every stakeholder particularly the host communities as part and parcel of Shell corporate family. The ground norm for sustainable corporate social responsibility is about capacity and commitments of concerned business entity to evolve a system where stakeholders' particularly host communities are allowed to evolve; and drive the process leading to enduring and sustainable partnership. It also enjoins allowing stakeholders to take ownership. 
Unfortunately, the essential ingredient of sustainable corporate social responsibility (CSR) activities is obviously lacking in Shell approach in the Niger Delta region. It does appear, Shell was merely acting out briefs of archaic Milton Friedman in its approach to corporate social responsibility (CSR) which focuses on maximizing profit even at the expense of critical stakeholders. Shell does not need to be told that this approach is no longer fashionable in the present and modern day business configuration. Corporate stakeholders particularly host communities in the present era are very much aware of their rights and interests. Shell does not look serious and strategic in her CSR activities. Aside from the fact that shell fell into common pitfalls of average corporate organisation in Nigeria which according to (Ahonsi.2010) treated Corporate Social Responsibility (CSR) as add- on residual and non-core activity. The lakaideiscal non-core residual CSR attitude subsumes the important role of stakeholders. Instead of being strategic, most companies in Nigeria often sees CSR budget as slush fund for illegally settling regulatory authorities and so-called leaders of host communities. They waste valuable resources on short term public relation demands and to curry favour from public officials. The predictable effect of these CSR anomalies in Nigeria include hostilities and all manner of frustrations such as the experience of Shell Petroleum Development Corporation (SPDC). The only antidote is to jettison this dimension of corporate social (ir)responsibility and adopt strategic, purposeful, well-focused change-oriented social responsibility agenda that put stakeholder's engagement particularly host community on the front burner!

\section{CONCLUSION}

It is the conclusions of this study that exigencies of modern business activities on corporate practices underscores need to acknowledge stakeholders interests and also endeavor to carry stakeholders' along for sustainable business practices. The Shell experience in Niger Delta region points to ineffectiveness in the use of issue management approach to CSR practices which is very common to most companies in developing countries. Issues management is too simplistic it is a lazy-man approach to CSR practices. It is also an indication of lack of serious commitments to sustainable CSR practices.

The frustrating encounter of Shell with its host communities in Niger Delta region has underscores the fact that stakeholders' strategic involvement is the best form of maximizing the benefits of CSR activities by corporate organizations.

This result would have been totally different if Shell had worked to incorporate its host communities in its CSR practices using the taking ownership model. The frustrating experience of Shell could also have been avoided if Shell had lived up to the expectations of her host communities. Stakeholders particularly host communities in this circumstance, cherish and respect their involvements. If shell had pro-actively involved its host communities, the stakeholders' are bound to commit themselves to the cause of the organizations. Rather than taking arms, stakeholders will rather defend their cause, no matter what it takes. The reason for this is prima-facie involvement that has precipitated a boisterous partnership necessary for efficient business/stakeholder relationship.

\section{ACKNOWLEDGEMENT}

The author is grateful to Mark Evans Associates Singapore for sponsoring participation at the $2^{\text {nd }}$ Middle CSR Forum, Dubai, United Arab Emirate, the outcome of which forms the background for this research output

\section{References}

Asolo Adeyeye, A 2005 .New Global Business Moral Order and Business Activities inDeveloping Countries.:The Nigerian Experience. Hooker.J \& Madsen.P (eds). International Corporate Responsibility Series Vol $2285-302$. 
Adewole, A. (2018). Corporate Social Responsibility (CSR) Practices and the Challenge of Taking Ownership: A Case Study of Frustrations of Shell Petroleum Development Company in Niger-Delta Region of Nigeria. Advances in Social Sciences Research Journal, 5(1) 96-107.

Asolo Adeyeye, A 2006.: WTO, Multilateral Trade Agreements in Africa and the Challenge of Establishing United Nation Global Regulatory Agency. A Paper Presented at International Conference on WTO Trade Agreements and Impact on Poverty and Inequality in Developing Countries. Ben-Gurion University of the Negev. Beer-Sheba Israel March 1-2.

Asolo Adeyeye, A 2006: Malaysian SME's. Global Opportunities and the Challenge of Global Business Moral Order. Ndubisi. N. O. and N.O. Saleh.(eds). Small and Medium Enterprises (SME's): Malaysian \& Global Perspectives. Pearson/Prentice Hall. Malaysia. Page 319-329.

Asolo Adeyeye, A (2007)/. Corporate Social Responsibility, Self-Regulation and the Problems of Unethical Practices in Africa: A Case for the Establishment of United Nations Global Business regulatory Agency. Controversies in International Corporate Responsibility series. Vol.3. page 69 - 81

Buchholz R (1991): “Corporate responsibility and the Good Society, from Economy to Ecology” Business Horizon, July-August. p.19

BBC News. Nigerian Senators Threaten Shell http/www.bbc.co.uk/2/hi/business/ 4060223.stm

Bosen Li Hilin, (2008) Vandalisation rampant in Niger-Delta Region of Nigeria. http//www news.xinhuanet.com/English 07-12.

Bowie. N. , (1991) New Direction in Corporate Social Responsibility. Business Horizons 34, (4) 56-65

Chinedu I. \& Chinua. A., (2001) The Niger Delta Issues, Challenge and Opportunities For Equitable Development Nigeria World features. Thursday March 8.

Clarkson. M.B.E A Stakeholder Framework for Analyzing and Evaluating Corporate Social Performance Academy of Management Review 20: 92-117

CNN.com, (1995), Shell Admits Blame in Nigeria,

http//www.edition.cnn.com/2004/WORLD/Africa/ob/11/nigeria.shell/index.wme

Commission for the European Communities (2001) Green Promoting a European framework for corporate social responsibility, Brussel. CEC.

Commission for the European Communities (2001). Green Paper: Promoting a European framework for Corporate Social Responsibility, Brussel, CEC.

David Henderson, (2004). The Role of Business in the Modern World: Progress, Pressures and Prospects for the Market Economy, Washington, Competitive Enterprises Institute, , 10.

Davis K., (1978). The Case For and Against Business Assumption of Social Responsibilities. Academy Management of Journal, 16, $312-322$.

Ensebius Mbidoka (2004). The Ethical Evaluation of Shell BP in Nigeria via-a-vis the Ogoni Case, Nigeria World, Wednesday May, 19.

Evan. M. Freeman. R.E, (1993). A stakeholder Theory of the Modern corporation in G.D Chryssides J.H. Kaler (Eds) An Introduction to business Ethics, Chapmans Hall,.

Fact sheet on ogoni Struggle www.ratical.org/corporations/facts/html Accessed 18/6/2014

Freeman, E. (1984). Strategic Management: A Stakeholder Approach, Boston Pitmans,.

Godwon Emakpe, (2008). Nigeria: Gas flowing-Niger-Delta Youth Sue Shell, Total, Exxon Mobil, Chevron others, Leadership Newspapers, Abuja, $3^{\text {rd }}$ April,.

Gulbaridsen. L.H. \& Moe. A, (2005), Oil Company CSR Collaboration in New Petrol-States, Journal of Corporate Citizenship 20: 52-64.

Hakeem, Ijaiya. Challenges of Corporate Social Responsibility in the Niger-Delta Region of Nigeria. Journal of Sustainable Development, Law and Policy, Vol 30 N0 1 institute of Oil, gas, energy, Environment and sustainable Development, Afe Babalola University, Ado Ekiti, PP 1 - 17.

Jones. T.M., (1980). Corporate Social Responsibility Revisited Redefined, California Management Review 22. 5967.

Kaler J. (1999). Understanding Participation, Journal of Business Ethics, 21, 125-135

Kingsley K. Tony N, (1999). Nigeria: Country in Focus African Recovery Vol. 13 No.1

Kingsley .k. \& Tony.N. (1999). Nigeria: Country in focus: African Recovery Vol. 13; No 9. 
Marsoden. C. \& Andriof. J. (1998). Toward and Understanding of Corporate Citizenship and How to Influence Citizenship Studies 2, 329-352

Micheal Jensen, (2001).Value Maximization, Stakeholder's Theory and the Corporate Objective Formulation. Journal of Applied Corporate Finance, Fall 8 - 21.

Nik Ogbuile, (2008). In Defence of Shell, The Guardian, Tuesday, October, Lagos Nigeria.

Obi, Akwani Shell Cuts Nigeria Jobs by 43 percent: Declining Production Due to unrest. http//www/university.com/villages/global/business.shellcutsjob

Papineau. D.\& Kiely. M. Participation (1996). Evaluation in a Community Organization: Fostering Stakeholders Empowerment and Utilization, Evaluation and Programme Planning 19, 79-93.

Prieston . L.E., Pokhl. J.E \& Rosen H.D. (2004). Implementing CSR in China through Stakeholders Involvement in Hooker. T. \& Madsen P (eds) International Corporate Responsibility, International Management Series (Vo 3) Carnegie Mellon University Press pp. 307.

Proston L.E. \& Polk.J.E \& Rosen. H. O. (2004. Implementing CSR in China through stakeholders'Involvement in Hooker.J. \& Madsen. P (eds), International Corporate Responsibility. International management series Vol. 3, Carnegie Mellon University Press, PP. 307.

Shell Petroleum Development Company (SPDC). Shell in the community, www.shell.com.ng/enuvirnment.sociaty/shell in the society html. Accessed 18 ${ }^{\text {th }}$ August, 2015.

Van Marrewijile. M. (2003) Concepts and Definition of CSR and sustainability: Journal of Business Ethics 44. 95 105

Watts M.J. (2005). Righteous Oil? Human Rights, The oil complex and Corporate Social Responsibility, Annual Review of Environment Resources 30: 373 - 407.

Windsor. D. (2001). The future of Corporate Social Responsibility: The International Journal of Organizational Analysis 9, 225-256. 